\title{
Preliminary study of rambutan (Nephelium lappaceum) seed as potential biocoagulant for turbidity removal
}

\begin{abstract}
This experiment was performed to determine the ability of the coagulation performance of rambutan seed in comparison to alum for potential use in turbidity removal in water and wastewater treatment industry. Experiments were conducted to find the optimum operating conditions for coagulation process such as coagulant dosage and $\mathrm{pH}$ and also suitable extracting solvent for the active agent (distilled water, $\mathrm{NaCl}$ and $\mathrm{NaOH}$ ). $1 \mathrm{M} \mathrm{NaCl}$ was found to be an effective solvent for extracting the active coagulant agent in rambutan seed and gave about $99 \%$ turbidity removal. The optimum rambutan seed dosages and $\mathrm{pH}$ was $100 \mathrm{mg} / \mathrm{l}$ and $\mathrm{pH} \mathrm{3}$, resulting in $>90 \%$ turbidity removal. In order to reduce dependency on alum, 50\% alum and 50\% rambutan seed as coagulant combination was used in the order of alum first followed by rambutan seed. The highest turbidity removal of $99 \%$ was achieved compared to when using alum (91\%) and seed (88\%) alone. Rambutan seed coagulant exhibited faster sedimentation time due to bigger flocs formation and also smaller sludge volume than alum. The results suggest potential of using rambutan biomass as biocoagulant.
\end{abstract}

Keyword: Alum; Natural coagulant; Protein; Rambutan seed; Solvent; Turbidity 